\title{
Carbon sequestration potential of mango orchards in India
}

\author{
A. N. Ganeshamurthy*, V. Ravindra and T. R. Rupa \\ Indian Institute of Horticultural Research, Bengaluru 560 089, India
}

Estimates of carbon stocks and stock changes in fruit orchards are necessary under the United Nations Framework Convention on Climate Change and the Kyoto Protocol. In this direction we estimated the carbon stocks in cultivated mango orchards in India using an exclusive allometric equation developed for estimation of tree biomass of grafted mangoes. Extensive tree, litter, weed and soil samples were collected for estimation of carbon pools by grouping mango areas based on similarity of tree canopy, climate, and dominance of mango varieties grown in these regions. The carbon held in these pools was then compiled and national-level carbon storage in cultivated mango orchards was computed by multiplying with the area occupied by mango in these regions. The country as a whole has sequestered $285.005 \mathrm{mt}$ of carbon in its mango orchards. This is, however, very low compared to polyembrionic mango trees grown from seeds in the wild.

Keywords: Allometric equation, carbon sequestration, mango orchards, tree biomass.

AMONG the terrestrial ecosystems, forest ecosystems have been identified as the largest land carbon sink and account for more than half of the carbon stored in terrestrial ecosystems ${ }^{1,2}$. The Indian forests sequester about 5.3-6.7 Pg C (refs 3, 4). However, during first few years of establishment both forests and orchards may sequester similar amounts of carbon ${ }^{5}$. Researchers have studied the contribution of orchards to carbon cycle like $\mathrm{C}$ storage ${ }^{6}$, root respiration ${ }^{7-9}$ and net $\mathrm{CO}_{2}$ flux ${ }^{10}$. Compared to forest stands, the potential for $\mathrm{C}$ credits based on standing biomass for orchards growing in the same climatic zone is limited. Most of the available information on orchards is from temperate regions, particularly from apple and citrus orchards. For example, it is reported ${ }^{5}$ that the New Zealand orchards (25 years old) roughly sequester about 70 tonne $\mathrm{C} \mathrm{ha}{ }^{-1}$, but in the same climatic region Pinus radiata forest stands sequester about 300-500 tonne carbon $\mathrm{ha}^{-1}$. There are limitations in such comparisons as different criteria were followed in both estimations. For example, in orchards the tree biomass was only considered ignoring indirect $\mathrm{C}$ emissions associated with orc-

*For correspondence. (e-mail: angmurthy@gmail.com) hard management practices which involve periodic input of organic materials and the decomposition rate of soil organic matter ${ }^{11}$. Published work on carbon sequestration in orchards mainly ignored the role of litter fall like flowers, fruits, leaves, pruned biomass, microbial respiration and rhizo deposition in the overall $\mathrm{C}$ balance of an orchard. Further partitioning of $\mathrm{C}$ in orchards to different organs of the fruit trees depends on genotype, tree age, planting density, fruit yield, canopy management and input additions ${ }^{12}$.

One of the options for reducing the rise of greenhouse gas (GHG) concentration in the atmosphere and thus possible climate change is to increase the amount of $\mathrm{C}$ removed by and stored in perennial plants. But due to large-scale industrialization and increased population, the forest area is declining. However, the perennial fruit orchards area is on the increase ${ }^{13}$. Nevertheless, orchards do have a potential similar to forests, but on a lower scale because of indirect $\mathrm{C}$ emissions associated with orchard management practices ${ }^{14-17}$. It has been shown that by practising conservation horticulture we can attain $\mathrm{C}$ sequestration levels in mango orchards similar to forest ecosystem $^{18}$. An estimate of $\mathrm{C}$ sequestration potential of fruit orchards in India is therefore essential for any strategic planning, offsetting GHG emissions and for trading carbon.

Mango is the major fruit crop of India and it is evergreen. It is grown in seasonally moist tropical climate having a distinct dry and wet season. There is a strong seasonality of photosynthetically active radiation usually being much larger in late wet season than in the dry season.

Two types of mango population occur in India - the wild poly embryonic mango and the cultivated grafted mango. Estimates of the population and area occupied by wild poly embryonic mango are not available, but surely must be a sizable area as India is the origin of mangoes. Cultivated mango occupies an area of nearly 2,263,000 ha and has great potential for carbon sequestration ${ }^{13}$. The area is further expected to increase given the importance gained by horticulture sector in government policies in recent years. It is essential to have a national database on the $\mathrm{C}$ sequestration by cultivated mangoes in India. This communication reports estimates of $\mathrm{C}$ sequestration in mango orchards of India.

Mango is grown in every state of India and the area $(2,263,000 \mathrm{ha})$ varies extensively with large localized 
Table 1. Grouping of states for sampling purpose

\begin{tabular}{cll}
\hline Group no. & \multicolumn{1}{c}{ State } & \multicolumn{1}{c}{ Popular varieties } \\
\hline 1 & Bihar, Chattisgarh, Jharkhand, Madhya Pradesh & Jardalu, Langra, Chaunsa, Gulaab Khaas \\
2 & Haryana, Punjab, Rajasthan, Uttar Pradesh, & Dusheri, Langra, Chaunsa \\
3 & Jammu and Kashmir, Himachal Pradesh, Uttarakhand, & Chaunsa, Dusheri, Langra \\
4 & Karnataka & Totapuri, Raspuri, Badami \\
5 & Andhra Pradesh, Telangana & Banganapalli, Totapuri \\
6 & Tamil Nadu & Neelam, Mulgoba \\
7 & Kerala, Goa, Gujarat, Maharashtra, Others & Alphonso, Kesar \\
8 & West Bengal, Odisha and Tripura & Himsagar, Amrapali \\
9 & Andaman and Nicobar Islands, Assam, Arunachal, Mizoram, Nagaland & Mixed varieties \\
10 & Others & Mixed varieties \\
\hline
\end{tabular}

pockets located in different regions and has gained varietywise recognition like Dusheri, Langra and Chaunsa in the Indogangetic plain, Alphonso in Konkan region, Totapuri, Raspuri and Badami in Karnataka, Banganapalli in Andhra Pradesh and Telangana, Kesar in Gujarat, Himsagar in West Bengal, Neelam and Mulgoba in Tamil Nadu, etc. (Table 4) Hence it is a practical difficulty to sample over this large area. Further ecological grouping is not possible as the mango database is available only on political boundary basis. Hence for sampling purpose, the mango-growing states were grouped based on similarity of tree canopy, climate and dominance of mango variety grown in these regions (Table 1). Extensive survey was conducted in these regions for recording allometric data. From each region randomly 100-350 economically bearing orchards (mostly tree age of about 25 years) were sampled to obtain a fairly representative sample of the orchards from these states.

As mentioned above, allometric data were collected from randomly selected trees from each of the regions listed in Table 1. All the orchards selected contained only grafted trees and hence we followed the allometric equation developed by Ganeshamurthy et al. ${ }^{19}$ for grafted mangoes for estimating the above ground and below ground tree biomass as there was no scope for recording the diameter at breast height $(\mathrm{DBH})$, a parameter necessary for using general allometric equation for estimating tree biomass. The measurement included the number of primary branches and girth of the primary branches. Briefly, the allometric equation was developed through destructive sampling of 74 mango trees covering the age group from 3 to 85 years. Allometric parameters such as number of primary and secondary branches, girth of primary and secondary branches, tree height, tree volume, basal diameter and diameter below graft union (DBGU) were measured on 74 randomly selected mango trees of different age groups: 3, 5, 8, 10, 12, 15, 16, 20, 45 and 85 years. Stem diameter (below graft union) was measured with a diameter tape. The height of the tree and diameter of the crown were measured with a Spiegel relaskop.

Different statistical models were used to estimate tree biomass like logistic model, Gompertz model and power model. As all these three models are a class of nonlinear regression model, as the derivatives of $Y_{\mathrm{t}}$ with respect to unknown parameters are functions of either of them, suitable nonlinear estimation procedure was followed for parameter estimation $^{20,21}$. SAS codes were developed to fit these nonlinear regression models. Based on the best fit, the power model was used for the estimation of tree biomass.

The power model is represented by the following equation

$$
Y_{t}=a X_{t}^{b}+\varepsilon_{t},
$$

$Y_{t}$ is the $t$ th trees ABG (above ground biomass), $X_{t}$ the $t$ th trees observations on PBG (primary branch girth) $\times$ NPB (No. of primary branches), $\varepsilon_{t}$ the error terms corresponding to difference between observed and expected tree ABG of $t$ th tree. For below ground biomass estimation, we followed the ratio of $1: 0.29$ as suggested by Ganeshamurthy et al. ${ }^{14}$.

Mature leaves were collected from 20 random trees from each sampling area (Table 2) for estimation of carbon content. These samples were pooled, washed and dried at $65^{\circ} \mathrm{C}$ in a hot-air oven till constant weight. The samples were then powdered for $\mathrm{C}$ estimation.

Similarly, samples of twigs representing tertiary branches and other smaller branches were also selected and processed for $\mathrm{C}$ estimation.

The bark and wood samples were collected from selected trees using a tree drill and processed for $\mathrm{C}$ estimation.

Representative area in such orchards where the litter was left unattended was sampled for collection of litter and weed biomass, and the samples were dried and processed for $\mathrm{C}$ estimation. Wherever the sampling was not possible, data were collected from published works from these states ${ }^{22,23}$.

The $\mathrm{C}$ content of these plant samples was estimated using a CHNS analyzer (Elementar) and expressed as per cent carbon in the sample.

The litter and weed biomass collected from these orchards were processed and analysed for their $\mathrm{C}$ content using a CHNS analyser (Elementar) and expressed as per cent $\mathrm{C}$ in the sample.

Soil carbon stock is the most difficult pool to obtain representative data. Practically it was difficult to arrive at a state-wise average soil organic carbon (SOC) as no 
RESEARCH ARTICLES

Table 2. Mean allometric parameters and tree carbon sequestered in mango orchards of India

\begin{tabular}{|c|c|c|c|c|c|c|c|c|}
\hline $\begin{array}{l}\text { States/ } \\
\text { Union Territory (UT) }\end{array}$ & $\begin{array}{l}\text { Number of } \\
\text { primary } \\
\text { branches* }\end{array}$ & $\begin{array}{c}\text { Mean girth } \\
\text { of primary } \\
\text { branches }(\mathrm{cm}) *\end{array}$ & $\begin{array}{c}\text { AGB } \\
\left.(\mathrm{kg} \mathrm{tree})^{-1}\right)\end{array}$ & $\begin{array}{l}\text { AGB carbon } \\
\left(\mathrm{kg} \mathrm{tre}^{-1}\right)\end{array}$ & $\begin{array}{c}\text { BGB } \\
\left(\mathrm{kg} \mathrm{tree}^{-1}\right)\end{array}$ & $\begin{array}{l}\text { BGB carbon } \\
\left(\mathrm{kg} \mathrm{tree}^{-1}\right)\end{array}$ & 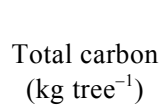 & $\begin{array}{l}\text { Total carbon } \\
\left(\text { tonne ha }{ }^{-1}\right)^{*}\end{array}$ \\
\hline Bihar & 3.6 & 157.1 & 1554.0 & 699.3 & 468.7 & 225.0 & 924.3 & 92.43 \\
\hline Chhatisgarh & 3.6 & 157.1 & 1554.0 & 699.3 & 468.7 & 225.0 & 924.3 & 92.43 \\
\hline Haryana & 3.5 & 156.20 & 1534.5 & 690.5 & 462.8 & 222.10 & 912.7 & 91.27 \\
\hline Himachal Pradesh & 3.5 & 105.30 & 952.4 & 571.4 & 287.2 & 176.80 & 748.2 & 74.82 \\
\hline Jammu and Kashmir & 3.5 & 105.30 & 952.4 & 571.4 & 287.2 & 176.80 & 748.2 & 74.82 \\
\hline Jharkhand & 3.6 & 157.1 & 1554.0 & 699.3 & 468.7 & 225.0 & 924.3 & 92.43 \\
\hline Madhya Pradesh & 3.6 & 157.1 & 1554.0 & 699.3 & 468.7 & 225.0 & 924.3 & 92.43 \\
\hline Punjab & 3.5 & 156.20 & 1534.5 & 690.5 & 462.8 & 222.10 & 912.7 & 91.27 \\
\hline Rajasthan & 3.5 & 156.20 & 1534.5 & 690.5 & 462.8 & 222.10 & 912.7 & 91.27 \\
\hline Uttarakhand & 3.5 & 105.30 & 952.4 & 571.4 & 287.2 & 176.80 & 748.2 & 74.82 \\
\hline Uttar Pradesh & 3.5 & 156.20 & 1534.5 & 690.5 & 462.8 & 222.10 & 912.7 & 91.27 \\
\hline Andhra Pradesh & 3.0 & 164.0 & 1571.5 & 707.2 & 474.0 & 227.5 & 934.7 & 93.47 \\
\hline Karnataka & 3.5 & 105.30 & 952.4 & 571.4 & 287.2 & 176.80 & 748.2 & 74.82 \\
\hline Kerala & 3.6 & 81.0 & 776.9 & 349.6 & 234.3 & 112.5 & 446.2 & 46.21 \\
\hline Tamil Nadu & 3.5 & 81.8 & 777.9 & 466.8 & 234.6 & 144.4 & 611.2 & 61.12 \\
\hline Telangana & 3.0 & 164.0 & 1571.5 & 707.2 & 474.0 & 227.5 & 934.7 & 93.47 \\
\hline Goa & 3.6 & 81.0 & 776.9 & 349.6 & 234.3 & 112.5 & 446.2 & 46.21 \\
\hline Gujarat & 3.6 & 81.0 & 776.9 & 349.6 & 234.3 & 112.5 & 446.2 & 46.21 \\
\hline Maharashtra & 3.6 & 81.0 & 776.9 & 349.6 & 234.3 & 112.5 & 446.2 & 46.21 \\
\hline $\begin{array}{l}\text { Andaman and Nicobar } \\
\text { and LD }\end{array}$ & 3.5 & 105.30 & 952.4 & 571.4 & 287.2 & 176.80 & 748.2 & 74.82 \\
\hline Assam & 3.5 & 105.30 & 952.4 & 571.4 & 287.2 & 176.80 & 748.2 & 74.82 \\
\hline Arunachal Pradesh & 3.5 & 105.30 & 952.4 & 571.4 & 287.2 & 176.80 & 748.2 & 74.82 \\
\hline Mizoram & 3.5 & 105.30 & 952.4 & 571.4 & 287.2 & 176.80 & 748.2 & 74.82 \\
\hline Nagaland & 3.5 & 105.30 & 952.4 & 571.4 & 287.2 & 176.80 & 748.2 & 74.82 \\
\hline Odisha & 3.6 & 93.5 & 908.0 & 408.6 & 273.9 & 168.5 & 577.1 & 57.71 \\
\hline West Bengal & 3.6 & 93.5 & 908.0 & 408.6 & 273.9 & 168.5 & 577.1 & 57.71 \\
\hline Tripura & 3.6 & 93.5 & 908.0 & 408.6 & 273.9 & 168.5 & 577.1 & 57.71 \\
\hline Others & 3.6 & 81.0 & 776.9 & 349.6 & 234.3 & 112.5 & 446.2 & 46.21 \\
\hline Mean & 3.507143 & 117.7214 & 1123.393 & 555.6 & 338.8071 & 180.25 & 733.025 & 73.58643 \\
\hline
\end{tabular}

* Mean of 100 trees. AGB, Above ground biomass; BGB, Below ground biomass.

single publication has done any such exercise in India to obtain a political boundary-based average SOC. However, the Forest Survey of India (FSI) ${ }^{24}$ has generated this information and the latest data were published in 2017. Since orchard ecosystem is closer to a forest ecosystem than an agro-ecosystem, and the sampled orchards are in the age group of about 25 years, we utilized the data for state average values of SOC. Briefly, the method used by FSI for collecting data on SOC is as follows: a representative site was selected from different regions of the state. While collecting soil sample, the floor was first swept and then a pit was dug and a composite sample was collected and analysed for organic $\mathrm{C}$ content and used for the calculation of SOC in the soil profile.

Carbon storage from mango trees was estimated based on dry matter and $\mathrm{C}$ content of the tree parts. The mean number of primary branches in orchard mango trees varied from 3.0 to 3.60 in different states. The average number of primary branches observed across the country was 3.507 (Table 2). The girth of primary branches differed in different state orchards depending upon climate and variety. The overall mean primary girth of mango trees varied from 81 to $164 \mathrm{~cm}$. The lowest girth $(81 \mathrm{~cm})$ was recorded in western India representing Konkan region, Kerala and Gujarat. While the maximum tree primary branch girth $(64 \mathrm{~cm})$ was recorded in Andhra Pradesh and Telangana region followed by Madhya Pradesh, Bihar, Jharkhand and Chhattisgarh region. This shows that there is a significant difference in the orchard mango tree robustness in different regions of the country.

Utilizing these two tree parameters the above ground biomass of mango trees was estimated following the allometric equation developed for grafted mangoes by Ganeshamurthy et $a l .{ }^{14}$. The above ground tree biomass in different states ranged from 776.9 to $1574 \mathrm{~kg}$ tree $^{-1}$. Averaged over different states, the above ground tree biomass was $1123.39 \mathrm{~kg}$ tree $^{-1}$. On per tree basis, the above ground tree biomass was more in groups 1, 2 and 5 representing major mango belts of the Indo-gangetic plain and Andhara Pradesh-Telangana region. The least was recorded in Konkan region, Kerala, Bay Islands and NEH region.

The above ground biomass was far less than that of ungrafted polyembryonic mango trees grown wild in forests and in isolated places in farmers' fields and avenues, which have tree diameter as large as $500 \mathrm{~cm}$ (refs 18, 19). 
RESEARCH ARTICLES

Table 3. Litter and weed biomass carbon in mango orchards of India

\begin{tabular}{|c|c|c|c|c|c|}
\hline States/UT & $\begin{array}{l}\text { Weed biomass } \\
\qquad(\mathrm{kg} / \mathrm{ha})\end{array}$ & $\begin{array}{l}\text { Weed carbon } \\
\qquad(\mathrm{kg} / \mathrm{ha})\end{array}$ & $\begin{array}{l}\text { Litter biomass } \\
\qquad(\mathrm{kg} / \mathrm{ha})\end{array}$ & $\begin{array}{l}\text { Litter carbon } \\
\qquad(\mathrm{kg} / \mathrm{ha})\end{array}$ & $\begin{array}{c}\text { Total carbon } \\
\text { content (tonne } \mathrm{ha}^{-1} \text { ) }\end{array}$ \\
\hline Bihar & 1360 & 632.4 & 1690 & 772.33 & 1.40473 \\
\hline Chhatisgarh & 1820 & 846.3 & 1460 & 667.22 & 1.51352 \\
\hline Haryana & 1210 & 562.65 & 1380 & 630.66 & 1.19331 \\
\hline Himachal Pradesh & 1380 & 641.7 & 1380 & 630.66 & 1.27236 \\
\hline Jammu and Kashmir & 1400 & 651 & 1380 & 630.66 & 1.28166 \\
\hline Jharkhand & 2040 & 948.6 & 1460 & 667.22 & 1.61582 \\
\hline Madhya Pradesh & 2320 & 1078.8 & 1460 & 667.22 & 1.74602 \\
\hline Punjab & 1100 & 511.5 & 1380 & 630.66 & 1.14216 \\
\hline Rajasthan & 880 & 409.2 & 1380 & 630.66 & 1.03986 \\
\hline Uttarakhand & 1760 & 818.4 & 1460 & 667.22 & 1.48562 \\
\hline Uttar Pradesh & 1850 & 860.25 & 1580 & 722.06 & 1.58231 \\
\hline Andhra Pradesh & 2020 & 939.3 & 1540 & 703.78 & 1.64308 \\
\hline Karnataka & 1960 & 911.4 & 1460 & 667.22 & 1.57862 \\
\hline Kerala & 580 & 269.7 & 1304 & 595.93 & 0.86563 \\
\hline Tamil Nadu & 2100 & 976.5 & 1460 & 667.22 & 1.64372 \\
\hline Telangana & 1850 & 860.25 & 1540 & 703.78 & 1.56403 \\
\hline Goa & 476 & 221.34 & 1304 & 595.93 & 0.81727 \\
\hline Gujarat & 1460 & 678.9 & 1440 & 658.08 & 1.33698 \\
\hline Maharashtra & 1780 & 827.7 & 1304 & 595.93 & 1.42363 \\
\hline Andaman and Nicobar \& LD & 2050 & 953.25 & 1304 & 595.93 & 1.54918 \\
\hline Assam & 2200 & 1023 & 1304 & 595.93 & 1.61893 \\
\hline Arunachal Pradesh & 2400 & 1116.0 & 1304 & 595.93 & 1.71193 \\
\hline Mizoram & 2400 & 1116.0 & 1304 & 595.93 & 1.71193 \\
\hline Nagaland & 2400 & 1116.0 & 1304 & 595.93 & 1.71193 \\
\hline Odisha & 1800 & 837 & 1450 & 662.65 & 1.49965 \\
\hline West Bengal & 2010 & 934.65 & 1450 & 662.65 & 1.5973 \\
\hline Tripura & 2400 & 1116 & 1304 & 595.93 & 1.71193 \\
\hline Others & 2000 & 930 & 1460 & 667.22 & 1.59722 \\
\hline Mean & 1750.21 & 813.85 & 1412.36 & 645.45 & 1.46 \\
\hline
\end{tabular}

Based on our experience at IIHR mean carbon content of weeds was assumed as $46.5 \%$ and litter carbon content as $45.7 \%$.

Similarly, the below ground biomass was estimated following the root-to-shoot ratio of 0.29 recommended by Ganeshamurthy et $a l .{ }^{14}$. The below ground biomass (Table 2) also followed a similar trend as above ground biomass. The tree root (below ground biomass) in different states ranged from 234.3 to $474 \mathrm{~kg}$ tree ${ }^{-1}$. Averaged over different states, the tree root biomass was $338.8 \mathrm{~kg}^{\text {tree }}{ }^{-1}$. On per tree basis, the tree root biomass was more in groups 1, 2 and 5 representing major mango belts of the Indo-Gangetic plain and Andhra Pradesh-Telangana region. The least was recorded in Konkan region, Kerala, Bay Islands and North East Hill (NEH) region.

Utilizing the mean $\mathrm{C}$ content of the above and below ground mango biomass, the total above ground and below ground $\mathrm{C}$ sequestered by grafted mangoes was estimated. The total $\mathrm{C}$ sequestered per tree across the country varied from 446.2 to $934.7 \mathrm{~kg}$ tree ${ }^{-1}$. On all-India basis, grafted mangoes sequestered $733.03 \mathrm{~kg} \mathrm{C}$ tree $^{-1}$. This is far below the values reported for polyembryonic wild mango trees $^{19}$, as the grafted mangoes are dwarfs, planted close and regularly canopy is managed to maintain short stature of the tree.

Weeds and litter represent the floor-level C sequestration. The annual weed biomass was estimated from the weed samples collected from sampled orchards in differ- ent states. For those states where sampling was not done, the data were obtained from other published works from the respective states. The weeds in mango orchards are mostly ephemerals in nature, seasonal and more during monsoon period. Due to tropical climate, weed biomass sometimes exceeds the litter biomass. It finally does enter into $\mathrm{C}$ cycle in the orchards contributing to SOC. Weed biomass varied from $476 \mathrm{~kg} \mathrm{ha}^{-1}$ in Goa to as high as $2400 \mathrm{~kg} \mathrm{ha}^{-1}$ in the NEH region. The mean weed biomass in mango orchards in the country as a whole was $1750.2 \mathrm{~kg} \mathrm{ha}^{-1}$. Orchards in NEH, Madhya Pradesh and Tamil Nadu had higher weed biomass and hence captured higher $\mathrm{C}$ followed by Jharkhand, Andhra Pradesh and Andaman and Nicobar Islands (Table 3). The differences are attributed to climate and the general management of mango orchards. This is reflected in the $\mathrm{C}$ capture through weeds in different regions.

The litter biomass in orchards varied from $1304 \mathrm{~kg} \mathrm{ha}^{-1}$ in Goa to as high as $1690 \mathrm{~kg} \mathrm{ha}^{-1}$ in Bihar followed by Uttar Pradesh, Andhra Pradesh and Telangana region. The mean litter biomass in mango orchards in the country as a whole was $1412.36 \mathrm{~kg} \mathrm{ha}^{-1}$ (Table 3 ). The litter biomass depended more on the variety, tree growth and fruiting behaviour. The mango yields are generally better in the Indo-Gangetic belt than those of the Konkan region 
Table 4. Soil $\mathrm{C}$ in mango orchards of India

\begin{tabular}{|c|c|c|c|}
\hline State/UT & $\begin{array}{l}\text { Soil carbon } \\
\text { (tonne/ha) }\end{array}$ & $\begin{array}{c}\text { Area } \\
(000 \text { ha })\end{array}$ & $\begin{array}{l}\text { Total soil carbon stock } \\
\quad(1000 \text { tonnes })\end{array}$ \\
\hline Bihar & 39.55 & 150.64 & 5957.812 \\
\hline Chhattisgarh & 49.67 & 73.99 & 3675.083 \\
\hline Haryana & 46.05 & 09.42 & 433.791 \\
\hline Himachal Pradesh & 55.09 & 41.52 & 2287.337 \\
\hline Jammu and Kashmir & 55.24 & 12.67 & 699.891 \\
\hline Jharkhand & 43.29 & 52.24 & 2261.470 \\
\hline Madhya Pradesh & 41.17 & 40.08 & 1650.094 \\
\hline Punjab & 48.84 & 06.85 & 334.554 \\
\hline Rajasthan & 26.21 & 05.00 & 131.050 \\
\hline Uttarakhand & 59.91 & 35.93 & 2152.566 \\
\hline Uttar Pradesh & 41.45 & 264.93 & 10981.350 \\
\hline Andhra Pradesh & 42.09 & 332.97 & 14014.710 \\
\hline Karnataka & 77.14 & 192.61 & 14857.940 \\
\hline Kerala & 75.77 & 69.11 & 5236.465 \\
\hline Tamil Nadu & 41.64 & 160.94 & 6701.542 \\
\hline Telangana & 39.49 & 180.62 & 7132.684 \\
\hline Goa & 52.42 & 4.77 & 250.0434 \\
\hline Gujarat & 44.04 & 153.18 & 6746.047 \\
\hline Maharashtra & 57.23 & 157.07 & 8989.116 \\
\hline Andaman and Nicobar \& LD & 101.12 & 0.05 & 5.056 \\
\hline Assam & 39.98 & 5.58 & 223.088 \\
\hline Arunachal Pradesh & 101.12 & 0.05 & 5.056 \\
\hline Mizoram & 40.26 & 0.89 & 35.831 \\
\hline Nagaland & 81.04 & 0.64 & 51.866 \\
\hline Odisha & 46.50 & 199.3 & 9267.450 \\
\hline West Bengal & 59.88 & 97.93 & 5864.048 \\
\hline Tripura & 54.80 & 11.64 & 637.872 \\
\hline Others & 42.00 & 6.98 & 293.160 \\
\hline Mean & 53.67821 & 80.98571 & 3959.892 \\
\hline
\end{tabular}

Total soil carbon stock from mango orchards in India $=110.877 \mathrm{mt}$.

and southern region. This is reflected in the litter biomass and carbon captured through litter.

As mentioned above, weed biomass exceeded litter biomass. The weeds are both dicot and monocot, and ephemerals in nature and are specific to the location. They are seasonal and more during monsoon period. With the tropical climate and mango being evergreen, the litter biomass could be less than the ephemeral weed biomass. The ephemeral weeds grow aggressively during monsoon season and produce biomass rapidly and can therefore surpass the quantity of litter from the evergreen mango. Hence the overall mean carbon credited from weed biomass was $813.85 \mathrm{~kg} \mathrm{ha}^{-1}$, as against the mean carbon credited by the litter, viz. $645.45 \mathrm{~kg} \mathrm{ha}^{-1}$ (Table 3). It finally enters into $\mathrm{C}$ cycle in the orchards contributing to SOC.

The proportion of litter fraction in the total $\mathrm{C}$ sequestration is very low. Generally in the forests the floor $\mathrm{C}$ represents less than $10 \%$ of the total $\mathrm{C}$ sequestered ${ }^{25}$. This is highly variable in fruit orchards as it depends upon the management followed in different orchards. If weeding is practised regularly, the fraction of this $\mathrm{C}$ will be low. In the present study, this proportion ranged from $0.996 \%$ in the Konkan and western regions to 2.81 in Assam and Madhya Pradesh region, with a mean of $2.04 \%$ across the mango orchards in the country. This shows that there are regional differences in weed and litter biomass production and it depends mainly on tree growth, variety, bearing habit of the orchards and the management practices followed in these regions. Despite its modest contribution to total $\mathrm{C}$, litter plays an important role in the $\mathrm{C}$ biogeochemical cycle as the interface between $\mathrm{C}$ in vegetation and soil.

The soil system attains a quasi-equilibrium stage after accumulation of dry matter and loss of SOC over time depending on land-use systems. Thus, SOC levels often show tooth-like cycles of accumulation and loss. After each change in land-use system, a period of constant management is required to reach a new quasi-equilibrium value $(\mathrm{QEV})$. In this way, SOC is stabilized to a new QEV of the changed situation in terms of new land-use patterns, vegetation cover and management practices. The SOC tends to attain a QEV with varying duration of 5001000 years in a forest system, 30-50 years in agricultural systems after forest cutting, 20-50 years under different agricultural systems and 30 years for horticultural system $^{16}$. Ganeshamurthy ${ }^{26}$ has shown that horticultural systems under these tropical land uses attain QEV in 25 years.

Indians have been cultivating mangoes for more than 4000 years. Emperor Akbar built the vast Lakhi Bagh 
RESEARCH ARTICLES

Table 5. Carbon pool compartment (tonne ha ${ }^{-1}$ ) in mango orchards of India

\begin{tabular}{|c|c|c|c|c|c|c|c|c|}
\hline State & $\begin{array}{l}\text { AGB tree } \\
\text { carbon }\end{array}$ & $\begin{array}{l}\text { Litter } \\
\text { carbon }\end{array}$ & $\begin{array}{l}\text { Weed } \\
\text { carbon }\end{array}$ & $\begin{array}{l}\text { Total above } \\
\text { ground carbon }\end{array}$ & $\begin{array}{l}\text { Root } \\
\text { carbon }\end{array}$ & $\begin{array}{l}\text { Soil } \\
\text { carbon }\end{array}$ & $\begin{array}{l}\text { Total below } \\
\text { ground carbon }\end{array}$ & $\begin{array}{l}\text { Total carbon } \\
\text { sequestered } \\
\text { in orchards }\end{array}$ \\
\hline Bihar & 69.93 & 0.772 & 0.632 & 71.335 & 22.5 & 39.55 & 62.05 & 133.385 \\
\hline Chhattisgarh & 69.93 & 0.667 & 0.846 & 71.445 & 22.5 & 49.67 & 72.17 & 143.615 \\
\hline Haryana & 69.05 & 0.631 & 0.5626 & 70.243 & 22.21 & 46.05 & 68.26 & 138.503 \\
\hline Himachal Pradesh & 57.14 & 0.631 & 0.642 & 58.412 & 17.68 & 55.09 & 72.77 & 131.182 \\
\hline Jharkhand & 69.93 & 0.667 & 0.949 & 71.546 & 22.5 & 43.29 & 65.79 & 137.336 \\
\hline Madhya Pradesh & 69.93 & 0.667 & 1.079 & 71.676 & 22.5 & 41.17 & 63.67 & 135.346 \\
\hline Punjab & 69.05 & 0.631 & 0.512 & 70.192 & 22.21 & 48.84 & 71.05 & 141.242 \\
\hline Rajasthan & 69.05 & 0.631 & 0.409 & 70.090 & 22.21 & 26.21 & 48.42 & 118.51 \\
\hline Uttarakhand & 57.14 & 0.667 & 0.818 & 58.626 & 17.68 & 59.91 & 77.59 & 136.216 \\
\hline Uttar Pradesh & 69.05 & 0.723 & 0.860 & 70.632 & 22.21 & 41.45 & 63.66 & 134.292 \\
\hline Andhra Pradesh & 70.72 & 0.704 & 0.939 & 72.363 & 22.75 & 42.09 & 64.84 & 137.203 \\
\hline Kerala & 34.67 & 0.596 & 0.270 & 35.536 & 11.15 & 75.77 & 86.92 & 122.456 \\
\hline Tamil Nadu & 46.68 & 0.667 & 0.977 & 48.324 & 14.44 & 41.64 & 56.08 & 104.404 \\
\hline Telangana & 70.72 & 0.704 & 0.860 & 72.284 & 22.75 & 39.49 & 62.24 & 134.524 \\
\hline Goa & 34.67 & 0.596 & 0.221 & 35.487 & 11.15 & 52.42 & 63.57 & 99.057 \\
\hline Gujarat & 34.67 & 0.658 & 0.679 & 36.007 & 11.15 & 44.04 & 55.19 & 91.197 \\
\hline Maharashtra & 34.67 & 0.596 & 0.828 & 36.094 & 11.15 & 57.23 & 68.38 & 104.474 \\
\hline $\begin{array}{l}\text { Andaman and Nicobar and } \\
\text { LD }\end{array}$ & 57.14 & 0.596 & 0.953 & 58.689 & 17.68 & 101.12 & 118.8 & 177.489 \\
\hline Assam & 57.14 & 0.596 & 1.023 & 58.759 & 17.68 & 39.98 & 57.66 & 116.419 \\
\hline Arunachal Pradesh & 57.14 & 0.596 & 1.116 & 58.852 & 17.68 & 101.12 & 118.8 & 177.652 \\
\hline Mizoram & 57.14 & 0.596 & 1.116 & 58.852 & 17.68 & 40.26 & 57.94 & 116.792 \\
\hline Nagaland & 57.14 & 0.596 & 1.116 & 58.852 & 17.68 & 81.04 & 98.72 & 157.572 \\
\hline Odisha & 40.86 & 0.663 & 0.837 & 42.360 & 16.85 & 46.50 & 63.35 & 105.71 \\
\hline West Bengal & 40.86 & 0.663 & 0.935 & 42.457 & 16.85 & 59.88 & 76.73 & 119.187 \\
\hline Tripura & 40.86 & 0.596 & 1.116 & 42.572 & 16.85 & 54.80 & 71.65 & 114.222 \\
\hline Others & 34.67 & 0.667 & 0.930 & 36.267 & 11.15 & 42.00 & 53.15 & 89.417 \\
\hline
\end{tabular}

near Darbhanga, growing over 100,000 mango trees. This was one of the earliest examples of grafting of mangoes, including the totapuri, rataul and kesar. However, commercial mango orcharding systems in India are about more than 250 years old. The orchards are generally replanted after 50-60 years or shifted to new areas and more frequently replanted in recent decades. In any case the soils under mango orchards aged 25 years and above have attained QEV stage after accumulation of dry matter and loss of SOC over time.

As mentioned it was difficult to obtain representative state averages of soil $\mathrm{C}$ stocks under mango orchards. Published information is mainly restricted to agriculture ecosystems and very few to horticultural ecosystems. Since state-wise SOC stocks information was available from forest ecosystems and as mango orchards represented more closely the forest ecosystems, we used the available data for computing $\mathrm{C}$ stocks by mango orchards. The soil $\mathrm{C}$ stocks in different states varied from 26.21 tonne $\mathrm{ha}^{-1}$ in Rajasthan to 101.12 tonne $\mathrm{ha}^{-1}$ in the Bay Islands (Table 4). Other than Bay Islands, the highest $\mathrm{C}$ stock in major mango belts was recorded in Karnataka (77.14 tonne $\left.\mathrm{ha}^{-1}\right)$.
The proportion of soil carbon in total $\mathrm{C}$ sequestered in mango orchards was higher than the tree carbon. It has been shown that the proportion of soil $\mathrm{C}$ in many instances exceeds the tree biomass carbon ${ }^{17}$. In this study the proportion of soil carbon to total sequestered $\mathrm{C}$ varied from $22.16 \%$ in Rajasthan, to $61.87 \%$ in Kerala with a mean of $46.97 \%$. Other than these, the highest soil C stock in major mango belts was recorded in Maharashtra $(54.77 \%)$, followed by Goa $(52.42 \%)$, West Bengal and Karnataka (50.24\%). Gupta ${ }^{27}$ reported that in mango orchards in Mangalore, the soil C stock was 41 tonne ha $^{-1}$ in the surface $50 \mathrm{~cm}$ depth. Chabra et $a .^{28}$ also reported that the soil $\mathrm{C}$ sequestered in Indian forest soils ranged from 37.5 tonne $\mathrm{ha}^{-1}$ in tropical dry deciduous forests to 92.1 tonne $\mathrm{ha}^{-1}$ in littoral swamp forests. Our values are for $100 \mathrm{~cm}$ depth soil profiles and are fairly similar to those reported in the literature for different regions.

Table 5 gives the $\mathrm{C}$ pool compartment of mango orchards. The mean $\mathrm{C}$ sequestered in mango orchards varied

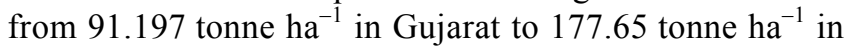
Arunachal Pradesh. However, in the main mango belts it varied from 134.5 tonne ha ${ }^{-1}$ in Uttar Pradesh, Andhra Pradesh and Telangana to 153.5 tonne $\mathrm{ha}^{-1}$ in Karnataka. 
Table 6. Carbon sequestered in mango orchards of India (tonnes)

\begin{tabular}{|c|c|c|c|}
\hline State & $\begin{array}{c}\text { Area } \\
(000 \mathrm{ha})\end{array}$ & $\begin{array}{l}\text { Total carbon sequestered } \\
\text { in } 1 \text { ha orchard (tonne } \mathrm{ha}^{-1} \text { ) }\end{array}$ & $\begin{array}{l}\text { Total carbon sequestered } \\
\text { in the region }(\mathrm{mt})\end{array}$ \\
\hline Bihar & 150.64 & 133.385 & 20.09312 \\
\hline Chhattisgarh & 73.99 & 143.615 & 10.62607 \\
\hline Haryana & 9.42 & 138.503 & 1.304698 \\
\hline Himachal Pradesh & 41.52 & 131.182 & 5.446677 \\
\hline Jammu and Kashmir & 12.67 & 131.342 & 1.664103 \\
\hline Jharkhand & 52.24 & 137.336 & 7.174433 \\
\hline Madhya Pradesh & 40.08 & 135.346 & 5.424668 \\
\hline Punjab & 6.85 & 141.242 & 0.967508 \\
\hline Rajasthan & 5 & 118.51 & 0.59255 \\
\hline Uttarakhand & 35.93 & 136.216 & 4.894241 \\
\hline Uttar Pradesh & 264.93 & 134.292 & 35.57798 \\
\hline Andhra Pradesh & 332.97 & 137.203 & 45.68448 \\
\hline Karnataka & 192.61 & 153.539 & 29.57315 \\
\hline Kerala & 69.11 & 122.456 & 8.462934 \\
\hline Tamil Nadu & 160.94 & 104.404 & 16.80278 \\
\hline Telangana & 180.62 & 134.524 & 24.29772 \\
\hline Goa & 4.770 & 99.057 & 0.472502 \\
\hline Gujarat & 153.18 & 91.197 & 13.96956 \\
\hline Maharashtra & 157.07 & 104.474 & 16.40973 \\
\hline Andaman and Nicobar \& LD & 0.05 & 177.489 & 0.008874 \\
\hline Assam & 5.58 & 116.419 & 0.649618 \\
\hline Arunachal Pradesh & 0.05 & 177.652 & 0.008883 \\
\hline Mizoram & 0.89 & 116.792 & 0.103945 \\
\hline Nagaland & 0.64 & 157.572 & 0.100846 \\
\hline Odisha & 199.3 & 105.71 & 21.068 \\
\hline West Bengal & 97.93 & 119.187 & 11.67198 \\
\hline Tripura & 11.64 & 114.222 & 1.329544 \\
\hline Others & 6.98 & 89.417 & 0.624131 \\
\hline Total & 2262.77 & 3602.283 & 285.005 \\
\hline
\end{tabular}

This is very low compared to wild polyembryonic mango trees grown from seeds. This is attributed to the fact that wild mango trees may reach $35-40 \mathrm{~m}$ or more height and live for several hundred years as against $8-10 \mathrm{~m}$ height and life of 40-50 years in cultivated grafted mangoes. Wild mangoes are fast-growing, erect trees with slender to broad and rounded upright canopy. On the other hand, grafted mangoes are dwarf statured, with relatively slow growth and branched at the surface. The wild trees are long-lived with some still producing fruit at 300 years of age. Whereas the orchard trees generally decline after 30 years. The wood density of wild mangoes is relatively higher (specific gravity 0.68$)^{29}$, than cultivated mangoes (specific gravity $0.52-0.55$ ). The tree is anchored by a long unbranched taproot and can descend to greater depth plus a mass of feeder roots as against a narrow root volume of grafted mangoes. The feeder roots of wild mangoes send down anchor roots which penetrate the soil to a depth of $1.2 \mathrm{~m}$ and spread laterally as far as $7.5 \mathrm{~m}$ as against less than $1 \mathrm{~m}$ depth and a spread of $2-3 \mathrm{~m}$ in grafted mangoes. All these parameters show that the biomass productivity of grafted mangoes is far lower than cultivated grafted mangoes in the orchards.

The state-wise $\mathrm{C}$ sequestration by orchard mangoes was computed by multiplying the per hectare $\mathrm{C}$ seques- tration by orchard mangoes with the area under mango cultivation in the respective states (Table 6). Andhra Pradesh and Telangana put together having maximum area under mango $(332.97+180.62$ thousand ha) had sequestered 69.98 million tonnes $(\mathrm{mt})$ of $\mathrm{C}$. This was followed by Uttar Pradesh $(35.58 \mathrm{mt})$, Karnataka $(29.57315 \mathrm{mt})$, Odisha (21.07 mt) and Bihar (20.09 mt). The country as a whole had sequestered $285.005 \mathrm{mt}$ of $\mathrm{C}$ in its mango orchards.

In order to formulate viable strategies for climate change mitigation, it is critical to understand, on the one hand, the land-use/land-use change dynamics in a given region. On the other hand, it is essential to examine the changes in $\mathrm{C}$ fluxes derived from land-use change patterns. One of the first crucial steps to achieve these goals is to obtain basic information on $\mathrm{C}$ content associated with various stocks of natural and man-made land-use/ land-use change classes at the regional level. Completing the present study involved a comprehensive effort above all in the integration of different methodologies for field work and data processing. The study generated unique information, both in terms of stocks and also allometric equations for grafted mangoes. It is thus a valuable first step for advancing our knowledge of the $\mathrm{C}$ cycle in cultivated mango ecosystems. Future efforts should consider 
other fruit crops orchards, coffee and tea estates and plantations of India and with larger sample sizes, to be able to determine $\mathrm{C}$ sequestered in perennial horticultural crops in the country as a whole.

The mangoes in India have mostly occupied degraded lands, although more and more orchards are coming under prime agricultural lands owing to the thrust given for horticulture in the country. Odisha, Madhya Pradesh, Chhattisgarh, Jharkhand and Bihar have large tracts of tribal land, and waste and degraded lands. These regions are suitable for a variety of mangoes like amrapali, Dasheri, Neelachal, Kesari, etc. Maharashtra itself has about $17 \%$ of the Konkan region as waste land. This is the region occupied by the famous Alphonso mangoes. In Konkan Goa and Karnataka also Alphonso mango occupied similar soils. Such regions are to be brought under productive mango orchards. Similar efforts may be made to bring the Chambal ravines under mangoes. Consequently, where forests have disappeared, such lands may be brought under mangoes, which reasonably imitate forests and sequester carbon in similar quantities and can augment climate-change risks. The administrators in these regions must use this information for claiming carbon credits to benefit the farmers and the local population.

1. Lal, M. and Singh, R., Carbon sequestration potential of Indian forests. Centre for Atmospheric Sciences, Indian Institute of Technology Environmental Monitoring and Assessment, 2000, 60, 315-327, 2000. Kluwer Academic Publishers, Printed in the Netherlands.

2. Hui, D., Deng, Q., Tian, H and Luo, Y., Climate change and carbon sequestration in forest ecosystems. In Handbook of Climate Change Mitigation and Adaptation (eds Chen, W.-Y. et al.), Springer Science + Business Media, New York, USA, 2015.

3. Dadhwal, V. K., Pandya, N. and Vora, A. B., Carbon cycle for Indian forest ecosystem: a preliminary estimated. In Global Change Studies: Scientific Results from ISRO-GBP (Subbaraya, B. H. et al.), Indian Space Research Organisation, Bengaluru, 1998, pp. 411-430.

4. Ravindranath, N. H., Somshekhar, B. S. and Gadgil, M., Carbon flows in Indian forests. Climate Change, 1997, 35, 297-320.

5. Kerckhoffs, L. H. J. and Reid, J. B., Carbon sequestration in the standing biomass of orchard crops in New Zealand. Hastings, New Zealand: New Zealand Institute for Crop and Food Research Ltd, Report, 2007, pp. 1-4.

6. Procter, J. T. A., Watson, R. L. and Landsberg, J. J., The carbon budget of a young apple tree. J. Am. Soc. Hortic. Sci., 1976, 101 579-582.

7. Blanke, M. M. and Kappel, F., Contribution of soil respiration to the carbon balance of an apple orchard. Acta Hortic., 1997, 451, 337-341.

8. Ebert, G. and Lenz, F., Annual course of root respiration of appletrees and its contribution to the $\mathrm{CO}_{2}$-balance. Gartenbauwissenschaft, 1991, 56, 130-133.

9. Sekikawa, S., Kibe, T. and Koizumi, H., Soil carbon budget in peach orchard ecosystem in Japan. Environ. Sci., 2003, 16, 97104.

10. Sofo, A. et al., Net $\mathrm{CO}_{2}$ storage in Mediterranean olive and peach orchards. Sci. Hortic., 2005, 107, 17-24.

11. Kimmins, J. P., Forest Ecology: A Foundation for Sustainable Management, Pearson Prentice Hall, New Jersey, 1997, 2nd edn, pp. 1-596.
12. Ganeshamurthy, A. N., Ravindra, V., Rupa, T. R. and Bhat, P. M., Carbon sequestration potential of mango orchards in tropical hot and humid climate of Konkan region of India. Curr. Sci., 2019, 116(8), 1417-1423.

13. NHB, Horticultural Statistics at a Glance, National Horticultural Board and Horticulture Statistics Division, Department of Agriculture, Cooperation and Farmers Welfare, Ministry of Agriculture and Farmers Welfare Government of India, 2017.

14. Selvaraj, A., Sivasankari, J., Dhivya, P., Thirunavukkarasu, A., Jayaraman and Perumal, K., Carbon sequestration potential, physicochemical and microbiological properties of selected trees Mangifera indica L., Manilkara zapota L., Cocos nucifera L. and Tectona grandis L., Biosci. Discovery, 2016, 7(2), 131-139.

15. Eneji, I. S., Obinna, O. and Azua, E. T., Sequestration and carbon storage potential of tropical forest reserve and tree species located within Benue State of Nigeria. J. Geosci. Environ. Prot., 2014, 2, 157-166.

16. Chandran, P., Ray, S. K., Durge, S. L., Raja, P., Nimkar, A. M., Bhattacharyya, T. and Pal, D. K., Scope of horticultural land-use system in enhancing carbon sequestration in ferruginous soils of the semi-arid tropics. Curr. Sci., 2009, 7, 1039-1046.

17. Ordóñez, J. A. B. et al., Carbon content in vegetation, litter, and soil under 10 different land-use and land-cover classes in the Central Highlands of Michoacan, Mexico. For. Ecol. Manage., 2008, 255, 2074-2084.

18. Ganeshamurthy, A. N., Ravindra, V., Panneerselvam, P, Sathyarahini, K. and Bhatt, R. M., Conservation horticulture in mango orchards: comparative effects of conventional and conservation management practices on soil properties of an Alfisol under seasonally dry tropical Savanna climate. J. Agric. Sci., 2016, 8, 1-16.

19. Ganeshamurthy, A. N., Ravindra, V., Venugopalan, R., Mathiazhagan, Malarvizhi and Bhatt, R. M., Biomass distribution and development of allometric equations for non-destructive estimation of carbon sequestration in grafted mango trees. J. Agric. Sci., 2016, 8, 201-211.

20. Seber, G. A. F. and Wild, C. J., Nonlinear Regression, 1989, John Wiley, New York, USA; http://dx.doi.org/10.1002/0471725315

21. Venugopalan, R. and Shamasundaran, K. S., Nonlinear regressions: a realistic modeling approach in horticultural crop research. J. Indian Soc. Agric. Stat., 2003, 56, 1-6.

22. Venkateswarlu, J., Effect of resource management system for dry lands of India. Adv. Soil Sci., 1987, 7, 165-121.

23. Ganeshamurthy, A. N., Dinesh, R., Ravisankar, N., Nair, A. and Ahlawat, S. P. S., Land resources of Andaman and Nicobar Islands, Central Agricultural Research Institute, Port Blair, 2002, p. 134.

24. FSI, Carbon stocks in India's forests. In India State of Forest Report 2017 Chapter 8.0, Forest Survey of India, 2017, pp. 120-136.

25. Usuga, J. C. L., Toro, J. A. R., Alzate, M. V. R. and Tapias, A. J. L., Estimation of biomass and carbon stocks in plants, soil and forest floor in different tropical forests. For. Ecol. Manage., 2010, 260(10), 1906-1913.

26. Ganeshamurthy, A. N., Annual Report, Indian Institute of Horticultural Research, Bengaluru, India, 2012.

27. Gupta, M. K., Soil organic carbon pools under different land use in Haridwar district of Uttarakhand. Indian For., 2011, 137, 1-8.

28. Chhabra, A., Palria, S. and Dadhwal, A. K., Soil organic carbon pools in Indian forests. For. Ecol. Manage., 2003, 173, 187-199.

29. Wood database, 2018; https://www.wood-database.com/mango/

ACKNOWLEDGEMENT. We thank the Indian Council of Agriculture Research-National Innovations on Climate Resilient Agriculture for financial support.

Received 15 April 2019; revised accepted 6 August 2019

doi: $10.18520 / \mathrm{cs} / \mathrm{v} 117 / \mathrm{i} 12 / 2006-2013$ 